\title{
回流式風洞における煙を使用した可視化実験装置*1 An Apparatus for Flow Visualization by Smoke in Circular Wind Tunnel
}

\author{
菊 池 孝 男*2 \\ Takao KIKUCHI
}

Key Words : Flow Visualization, Oscillating Wing, Unsteady Aerodynamics

\begin{abstract}
An apparatus for flow visualization around oscillating wing was designed and assembled. To validate the modern CFD. the experimental data not only about the pressure distributions on the wing surfaces but also the flow patterns around the wing are needed. The present system aims to offer the experimental information on the flow patterns around oscillating 2-D wings. In this report, the outlines of the driving mechanism for the 2-D wing and the smoke generator are presented together with the related other devices. It is shown that the system works well in the low-turbulence wind tunnel at NAL and expected that it can be used for the research of low speed unsteady aerodynamics and aeroelasticity.
\end{abstract}

\section{1.はじめに}

航空機の空力弾性問題では, フラッタ限界の推定やフラ ッタ制御のために精度の高い非定常空気力の推定が重要て ある. 近年, スーパー・コンピューターの著しい発展に伴 いナビエ・ストークス方程式を用いて非定常空気力を数值 計算することが精力的に行われている．昨今のCFDでは 翼面上の圧力分布データを検証データとして提供するのみ では不充分であり，流れ場の様子を可視化して提供するこ とが必要となって来ている。そこでCFD計算結果の検証 データを得るために，工作精度による特性の変化が少ない ことで計算結果の検証に最適な翼であるとして注目されて いる NASA GA(W)-1 翼型1) 22 次元翼模型を周期加振 し，その翼まわりの非定常流れ現象を調べるために煙りを 使用した可視化実験装置を製作した。

この装置では翼模型の回転軸の位置の違いによって翼ま わりの気流がどのように異なるのかを調べるために，回転 軸の位置を前緑から $10 \%$ と 64\%の場合について，平均迎 角，振動振幅，振動数，および風速を実験パラメーターと する実験を想定している. 実験は可視化装置の整備されて いない航技研の回流式低速風洞である「小型校正用低乱風 洞」で行う，本装置の特徽は，周期加振における翼模型の 平均迎角, 振動振幅, 振動数の変更をパソコンの指令で自 在に変更可能にした点にある。また，「排煙装置」を準備 したことにより長時間の連続実験が可能であるうえに，風 洞の風路を油煙で污すことは少ない．翼模型加振装置と可 視化実験装置の概要を速報する。

*1 平成 11 年 1 月 18 日原稿受理

*2 航空宇宙技術研究所

\section{2. 可視化実験装置の構成}

第 1 図に可視化実験装置のスケッチを示す．今回使用す る「小型低乱校正風洞2」山縮流部の絞り比が $9: 1$, 測定 部の大きさが [幅 $550 \mathrm{~mm} \times$ 高さ $650 \mathrm{~mm} \times$ 長さ1,500 $\mathrm{mm}$ ] の回流形である. 風洞の特性は, 風速範囲 1 65 $\mathrm{m} / \mathrm{s}$, 風速分布 $< \pm 0.1 \%$, 気流の乱れ $< \pm 0.05 \%$ （風速 $40 \mathrm{~m} / \mathrm{s})$ である. 翼模型取付用側壁の観測窓側は厚さ 10 $\mathrm{mm}$ の透明アクリル板を設置した．翼模型の回転軸が貫

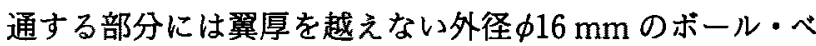
アリングを入れている. 翼模型は主にバルサと朴を使用 し、一部にジュラルミンを使用して製作している翼型 $\lceil\mathrm{NASA}-\mathrm{GA}(\mathrm{W}) \cdot 1 」$, 翼弦 $150 \mathrm{~mm}$, 翼幅 $550 \mathrm{~mm} の 2$ 次 元翼である。

加振機の加振機構を第 2 図を用いて説明する。翼模型の 回転軸（中空軸）(1)に固定したプーリ(2)はスチールベルト でスライドロッド(3)と熬がっている. スライドロッド(3)の 上端がコネクティングロッド(4)により回転斜板(5)と接続さ れ，回転斜板(5)はモー夕(6)で定速回転することにより振動 数 ( $\omega)(\max .8 \mathrm{~Hz})$ の周期加振が可能になる.モータ6 は回転斜板(5)の取付部の中心を回転中心にしいるプーリ(7) と共にモータ8によっって任意の角度に回転 $\left(0^{\circ} \sim \pm 15^{\circ}\right)$ して加振振幅 $(A)$ を決める.プーリ(7)とモータ(8)を載せ た回転ベース(9)同じ回転中心を持つプーリ10と一体にな っていて，モー夕@によって回転 $\left(0^{\circ} \sim \pm 55^{\circ}\right)$ し平均迎 角 $\left(\alpha_{\mathrm{m}}\right)$ を決める。 $\omega, A ， \alpha_{\mathrm{m}}$ はパソコンの指令で自在に 変更可能である.

一般に，煙吹出装置の設置場所は，気流速度の加速する 縮流部が適しているが3)，風洞利用の制約上集合胴に設置 することにした。煙は下部からのみ供給するので上下均等 に吹き出るようにするため，煙貯は煙吹出部を持つダクト と持たないダクトを上下で連結した構造にしている．煙貯 


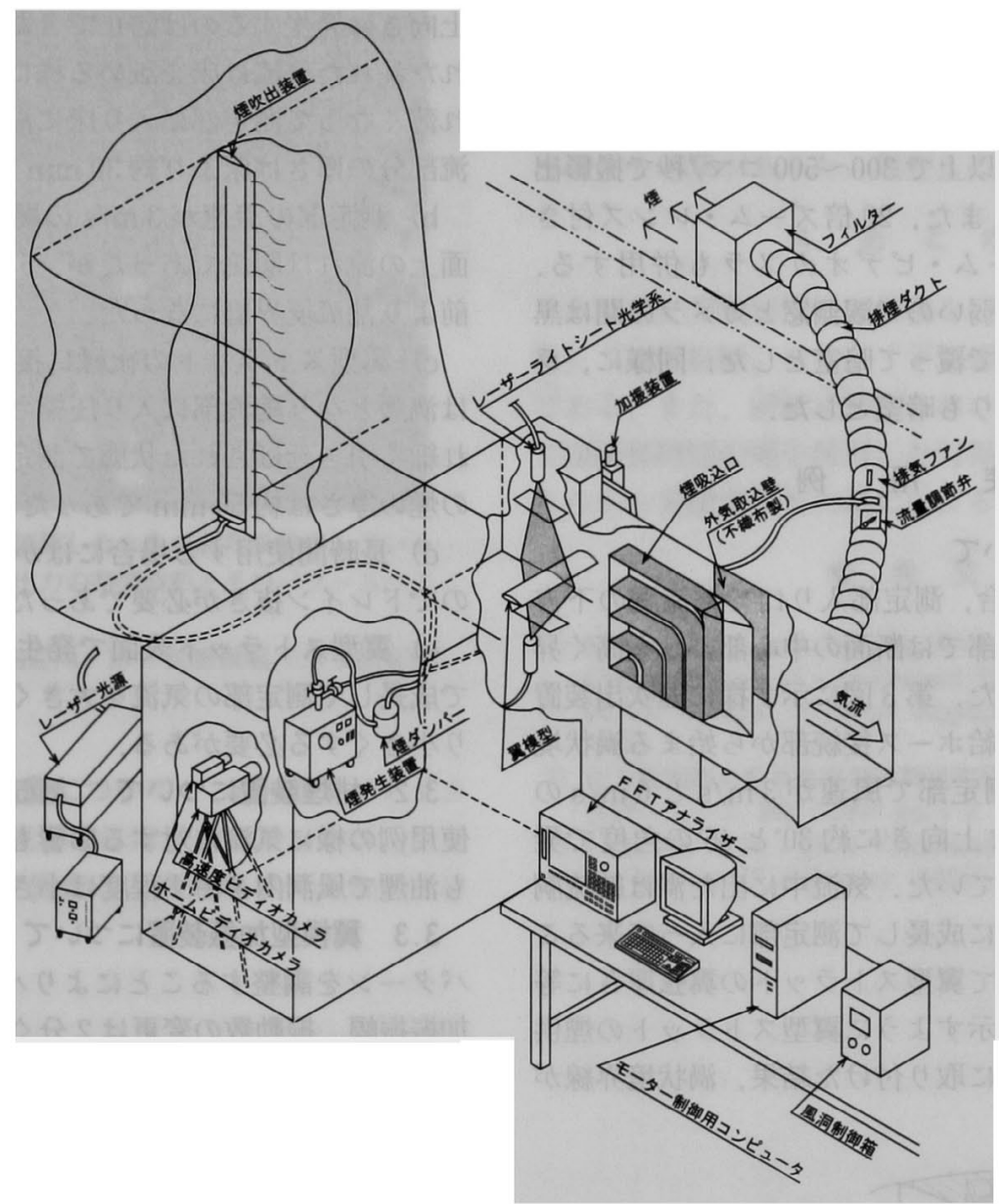

第 1 図 可視化実験装置スケッチ
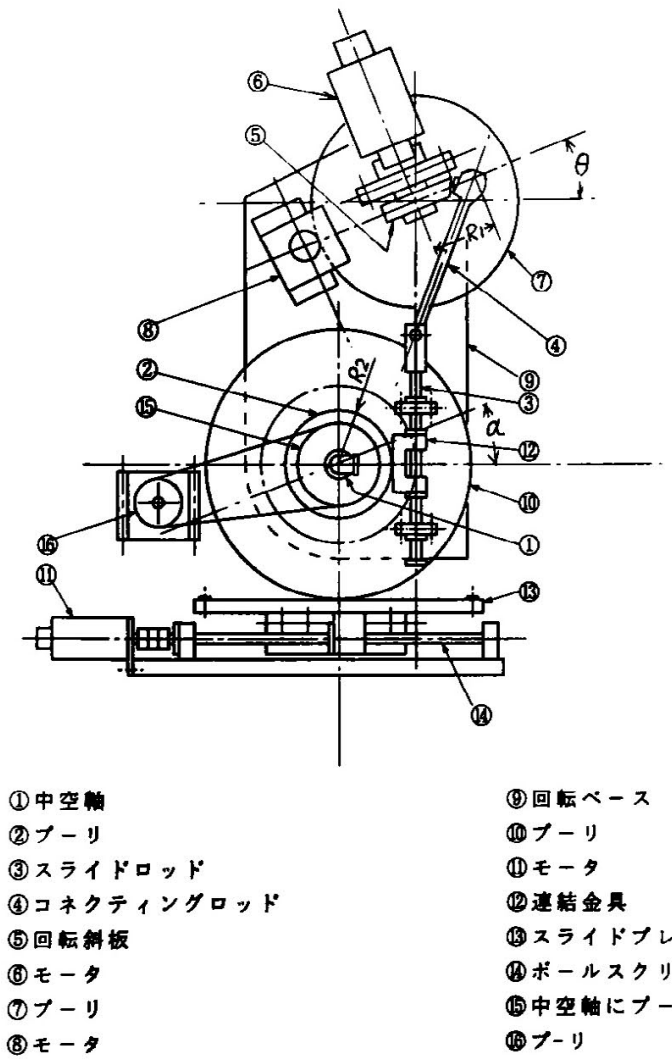

第2図
(8) 回枟ベース

(11)プーリ

(11) ₹-タ

(2)这蛣金具

(13) スライドプート

(1)ボールスクリュウ

(19)中空艄にプーリ

(16)フーリ

の煙は対称翼型をした煙吹出装置の片側にのみあるスリッ トからコアンダ効果によりシート状に表面に洛って下流に 向かって流れる。「煙吸込口」は閉塞率 19\%の大きさのも のを設置した．「煙吸込口」内の流路は薄い鋼板で入り口 から出口まで上下に 4 等分に分割し, 半径 $150 \mathrm{~mm}$ の円 弧で下に $90^{\circ}$ 曲げている，煙吸込口下部には水平方向に $90^{\circ}$ 曲がり，断面を矩形から円形に変換し，内部に気流を 整流するためのアルミハニカムを入り口と出口に装着して いるスチール製のダクトを接続している、この後に $\phi 320$ の布製ダクトを接続している. 定容量排気ファンを使用し ているので「流量調節弁」を使用して「煙吸込口」付近の 流速を微調節している．「排煙装置」で排出した分の流量 を補給するために「煙吸込口」の両側の測定部側壁に開口 部を作り，不織布を取り付け，測定部の気流の静圧と大気 圧との差圧を相殺する目的で大気が測定部に流入するよう にした。

照明装置の「Nd: YAGパルス・レーザー」の光は光 ファイバーを使用して測定部の上下壁の観湘空にセットさ れている，手動で $X, Y, Z$ 軸方向に移動・各軸まわり に回転可能なライト・シート光学系まで票いている、レー ザー光源の平均出力は最大 $25 \mathrm{~W}$ まて, パルス周波数は 4 $\mathrm{kHz} \sim 50 \mathrm{kHz}$ の間で可変であり, 高速度ビデオカメラと 
外部同期が可能である。

本可視化装置で想定される一番早い現象は風速 $9 \mathrm{~m} / \mathrm{s}$, 翼模型の振動数が $7.3 \mathrm{~Hz}$ の場合である。したがって，シ ヤッター速度 $1 / 4,500$ 秒以上で 300 500 コマ/秒で撮影出 来るカメラを準備した．また，20倍ズーム・レンス付き の $8 \mathrm{~mm}$ のカラー・ホーム・ビデオカメラも併用する. 煙からの反射光は非常に弱いので観測空とカメラの間は黒 色の薄いビニールシートで覆って暗室とした，同様に，ラ イト・シート光学系の回りも暗室とした。

\section{3. 使用例}

\section{1 煙吹出装置について}

a）実際に運転した場合，測定部入りロで縮流胴の下方 から大きい渦が生じ測定部では断面の中心部よりも高く昇 って測定部の気流を乱した，第 3 図に示す様に煙吹出装置 の翼型ストラットの煙供給ホース接続部から始まる渦状境 界線が発生していた。測定部で風速が $3 \mathrm{~m} / \mathrm{s}$ と $6 \mathrm{~m} / \mathrm{s} の$ とき渦状の境界線は各々上向きに約 $30^{\circ}$ と $45^{\circ}$ の角度で発 生し，その後流は剝離していた。気流中に出た渦は縮流胴 に入り加速され，強い渦に成長して測定部に入って来るこ とが分かった，対策として翼型ストラットの翼弦厚さに等 しい幅の端板を第 4 図に示すように翼型ストラットの煙供 給ホース接続部金具上部に取り付けた結果，渦状境界線が

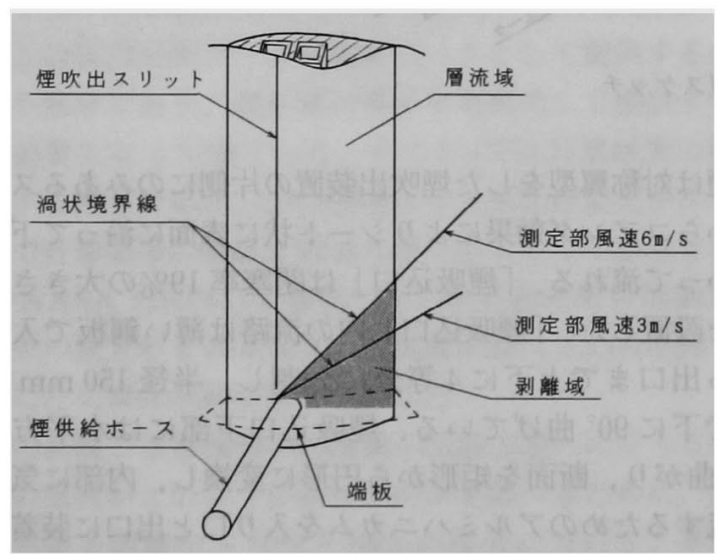

第 3 図 煙供給ホース接続部から発生する渦状境界線

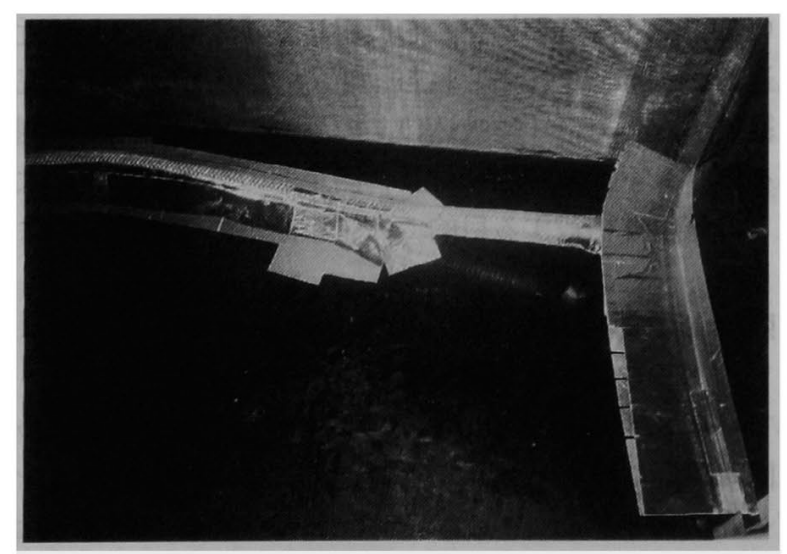

第 4 図 煙供給ホース接続部の端板
上向きに発生するのは防止できた．端板の下に押さえ込ま れた乱れた気流は床を舐める様にして縮流胴に入り压縮さ れ薄くなって測定部に入り床に浻って流れる．この時の乱 流部分の厚さは床より約 $30 \mathrm{~mm}$ であった.

b）剆定部の流速が $3 \mathrm{~m} / \mathrm{s}$ の場合には翼型ストラット表

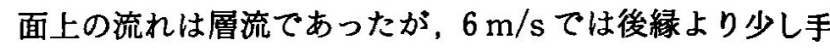
前より乱流境界層になった。

c）翼型ストラットの後縁に接続した単板を離れた後流 は渦層となり縮流部に入り圧縮されると共に，順次加速さ れ細く引き延ばされた状態で測定部に入って行く．测定部 の煙の厚さは約 $50 \mathrm{~mm}$ であった．

d）長時間使用する場合にはかなりのドレインが貯まる のでドレイン抜きが必要であった。

e）翼型ストラット表面で発生した小さな乱れは縮流䏤 で成長して測定部の気流を大きく乱すため表面荒さはかな り小さくする必要がある.

3.2 排煙装置について 第 5 図に示す「排煙装置」の 使用例の様に気流に対する影響も小さく，長時間使用して も油煙で風洞内を污す程度は小さかった。

3.3 翼模型加振装置について 前もってモータの駆動 パターンを調整することによりパソコンによる平均迎角， 加振振幅，振動数の変更は 2 分ぐらいで完了する . 第 6 図 は風速 $9 \mathrm{~m} / \mathrm{s}$, 平均迎角 $16^{\circ}$, 加振振幅 $5^{\circ}$, 設定加振振動 数 $7.3 \mathrm{~Hz}$ で翼模型を加振している時の迎角を検出してい るポテンショメーターの出力を FFT アナライザーで処理 し，パワースペクトルと時間履歴を得たものである. 設定 加振振動数 $7.3 \mathrm{~Hz}$ に対して翼模型は $7.375 \mathrm{~Hz}$ で振動し ている．また，パワースペクトルの形も頂部で一つの線に 重なり合う急峻な形をしているので設定に対してかなり良 い応答をしていることが判る。

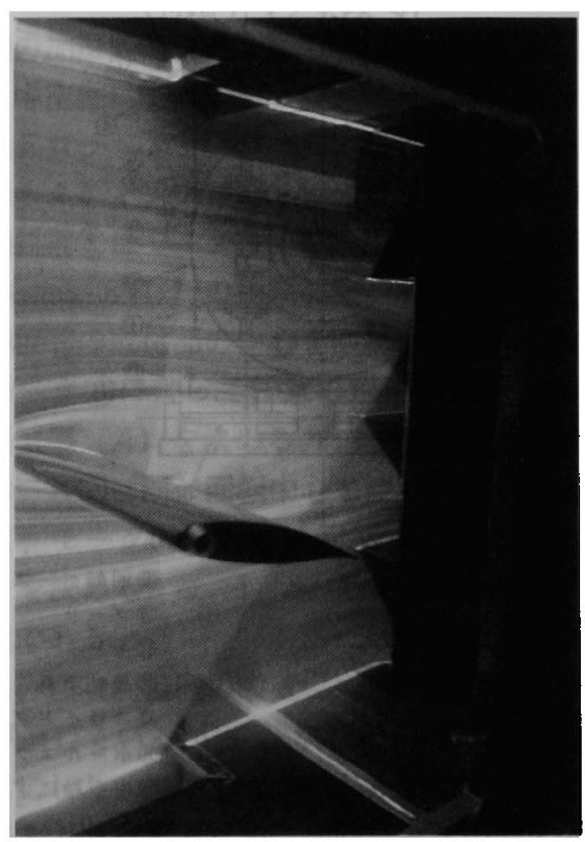

第 5 図「排煙装䀠」使用例 


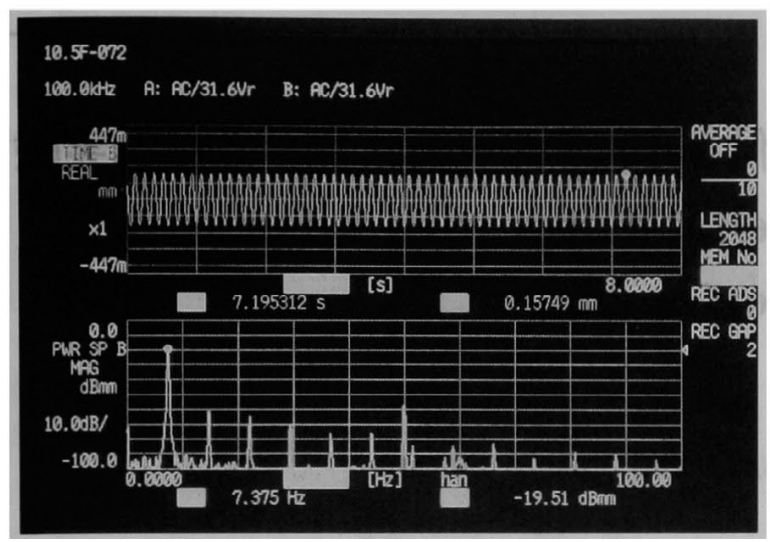

第 6 図 通風中に翼模型を加振したときの迎角を検出している ポテンショメータ出力の時間波形とそのパワースペク トル

風速, $9 \mathrm{~m} / \mathrm{s}$ ：平均迎角, $16^{\circ}$ : 加振振幅, $\pm 5^{\circ}:$ 設定加 振周波数, $7.3 \mathrm{~Hz}$

3.4 ビデオカメラと光量について ホーム・ビデオカ メラによる撮影において光量はほほ十分であったが、シャ ッター速度が $1 / 4,500 \mathrm{~s} て ゙$ 撮影した高速度ビデオカメラに
よる撮影において光量がかなり不足であったので画像処理 による画質改善が必要である.

3.5 その他 煙のシートが時々前後に $20 \mathrm{~mm}$ ぐらい 移動する現象があった．現在この理由は不明である。

\section{4.あとが}

本可視化実験装置は加振機をパソコンを使用して「振動 数」,「加振振幅」おうよび「平均迎角」を短時間に変更可能 である，また，回流式風洞において「排煙装置」を使用し て連続長時間の煙を使用した可視化実験が可能である。こ れらから実験効率を大幅に上げることが可能である。

\section{参 考 文 献}

1) McGbee, R. J. and Beasley, W. D. : Low-Speed Aerodynamic Characteristics of a 17-Percent-Thick Airfoil Section Designed for General Aviation Applications, NASA TN D.7428, 1973.

2）空力性能部大型低速風洞制御研究室: 小型低乱校正風洞完成, 航 技研ニュース, 352 (1988) pp. 1-2.

3) Lippisch, A. M. : Flow Visualization, Aeronautical Engineering Review, 17, February (1958), p. 25. 